\title{
Model Prediksi Kebutuhan Darah untuk Penderita Talasemia Mayor
}

\author{
Blood Need Prediction Model for Mayor Thalassemia Patients
}

\author{
Dwi Sarwani Sri Rejeki* Putri Pradani* Nunung Nurhayati** Supriyanto**
}

\begin{abstract}
*Fakultas Kedokteran dan Ilmu-ilmu Kesehatan Universitas Jenderal Soedirman, **Fakultas Sains dan Teknik Universitas Jenderal Soedirman
\end{abstract}

\begin{abstract}
Abstrak
Pada dua tahun pertama kehidupan penderita talasemia mayor, umumnya menderita anemia dan membutuhkan tranfusi darah. Penelitian ini bertujuan membuat model prediksi kebutuhan darah bagi penderita talasemia mayor. Penelitian observasional dengan desain studi pendekatan potong lintang ini dilakukan pada sampel 79 penderita talasemia mayor yang melakukan transfusi rutin minimal satu bulan satu kali di Rumah Sakit Umum Banyumas, selama tahun 2012. Analisis regresi linier ganda digunakan untuk membuat model prediksi. Hasil penelitian menunjukkan bahwa $80,7 \%$ kebutuhan darah penderia talasemia mayor dijelaskan oleh variabel usia, berat badan, dan kadar hemoglobin sedangkan 19,3\% dijelaskan oleh sebab-sebab yang lain. Rumus prediksi menyatakan setiap kenaikan usia 1 tahun maka kebutuhan darah akan bertambah sebanyak 0,816 mililiter dan setiap kenaikan 1 kilogram berat badan maka kebutuhan darah akan bertambah 13,4 mililiter serta apabila kadar hemoglobin mengalami penurunan $1 \mathrm{~g} / \mathrm{dL}$ maka kebutuhan darah akan bertambah sebesar 81 mililiter.
\end{abstract}

Kata kunci: Kebutuhan darah, model prediksi, talasemia mayor

\footnotetext{
Abstract

Patients with thalassemia major usually present within the first two years of life with severe anemia, need red blood cell transfusion. The objective of this study was to create a prediction model of blood transfusion need for patients with thalassemia mayor. This type of research was observational with cross sectional design. Samples are 79 patients with thalassemia major who perform routine transfusion at least once in a month at Banyumas hospital in 2012. Multiple linier regression analysis was used to create the model. The results showed that $80.7 \%$ blood requirements can be explained by variables of weight, haemoglobin level and age, while $19.3 \%$ is explained by other causes. Prediction formula states every increment of one year in age, the need for blood will increase by 0.816 millilitres and every increment of one kilogram of body weight, the need for blood will increase 13.4 millilitres,
}

and when the haemoglobin level decreased $1 \mathrm{gr} / \mathrm{dL}$ the need for blood will increase by 81 millilitres.

Keywords: Blood need, prediction model, thalasemia major

\section{Pendahuluan}

Talasemia adalah penyakit keturunan karena adanya kelainan pada satu atau lebih gen globin pada darah. ${ }^{1}$ Hemoglobin $(\mathrm{Hb})$ terdiri dari empat rantai globin, yaitu hemoglobin janin $(\mathrm{HbF})$ memiliki dua rantai alfa $(\alpha)$ dan dua rantai gamma $(\gamma)\left(\alpha_{2} \gamma_{2}\right)$ dan hemoglobin dewasa $(\mathrm{HbA})$ memiliki dua rantai alfa $(\alpha)$ dan dua rantai beta ( $\beta)\left(\alpha_{2} \beta_{2}\right){ }^{2}$ Talasemia $\alpha$ disebabkan oleh sintesis rantai $\alpha$-globin yang berkurang, sedangkan pada talasemia $\beta$ disebabkan oleh sintesis rantai $\beta$-globin tidak ada sama sekali dan sintesis rantai $\beta$-globin yang sangat kurang. Sintesis rantai $\beta$-globin yang tidak ada sama sekali menyebabkan kelainan berupa talasemia $\beta^{0}$ atau dikenal dengan nama talasemia $\beta$ mayor, sedangkan sintesis rantai $\beta$-globin yang sangat kurang menyebabkan kelainan berupa talasemia $\beta^{+}$atau dikenal dengan nama talasemia $\beta$ minor. ${ }^{1}$

Berdasarkan laporan World Health Organization tahun 2006, sekitar 5\% penduduk dunia diduga carrier talasemia, dan sekitar 370.000 bayi lahir dengan kelainan ini setiap tahunnya. United Nations International Children's Emergency Fund (UNICEF) memperkirakan bahwa 29,7 juta pembawa talasemia- $\beta$ berada di India dan seki$\operatorname{tar} 10.000$ bayi lahir dengan talasemia- $\beta$ mayor. ${ }^{3}$ Preva-

Alamat Korespondensi: Dwi Sarwani Sri Rejeki, Jurusan Kesehatan

Masyarakat FKIK Unsoed, Kampus Karangwangkal, Jl. Dr. Suparno

Purwokerto 53122,Hp.081328581788,e-mail:dwisarwanisr@yahoo.com 
lensi carrier talasemia di Indonesia sekitar $3-8 \%$, artinya 3 sampai 8 dari 100 orang Indonesia membawa sifat talasemia. ${ }^{4}$ Berdasarkan laporan Riskesdas, prevalensi talasemia di Jawa Tengah sekitar 5\%. ${ }^{5}$ Data penderita talasemia di wilayah Banyumas dan sekitarnya mengalami peningkatan secara signifikan. Yayasan Talasemia Indonesia (YTI) cabang Banyumas melaporkan sebanyak 44 penderita tahun 2008, meningkat menjadi 65 pada tahun 2009, meningkat 100 pada tahun 2010, meningkat 153 pada tahun 2011, dan pada tahun 2012 jumlah penderita meningkat menjadi $182 .{ }^{6}$

Talasemia diwariskan sebagai sifat kodominan autosomal. Pewarisan bentuk heterozigot menyebabkan talasemia minor atau sifat talasemia (carrier Thalassemia), biasanya tidak bergejala (asimtomatik) atau hanya bergejala ringan. Pewarisan bentuk homozigot menyebabkan talasemia mayor dengan anemia hemolitik yang berat. Permasalahan talasemia akan muncul jika carrier talasemia menikah dengan carrier talasemia sehingga $25 \%$ dari keturunannya akan mengalami talasemia mayor, 50\% kemungkinan anaknya menderita talasemia minor dan hanya 25\% kemungkinan anaknya mempunyai darah normal. ${ }^{7}$

Talasemia $\beta$ mayor sebagai penyakit genetik yang diderita seusia hidup akan membawa banyak masalah bagi penderitanya. Mulai dari kelainan darah berupa anemia kronik akibat proses hemolisis, sampai kelainan berbagai organ tubuh baik sebagai akibat penyakitnya sendiri ataupun akibat pengobatan yang diberikan. Penderita talasemia $\beta$ mayor dengan kadar hemoglobin $<10 \mathrm{~g} / \mathrm{dL}$ sebanyak $99,1 \%$, hal ini menunjukkan hampir seluruh penderita talasemia $\beta$ mayor mengalami anemia. Sampai saat ini, transfusi darah masih merupakan penatalaksanaan utama untuk menanggulangi anemia pada talasemia $\beta$ mayor. ${ }^{8}$ Hasil penelitian sebelumnya menyatakan penderita talasemia mulai transfusi ratarata berusia 3,78 tahun, dan frekuensi transfusi sebagian besar 1 bulan 1 kali $(87,5 \%)$. Salah satu penatalaksanaannya yaitu menyediakan jumlah kebutuhan darah oleh pihak penyedia darah untuk transfusi agar kebutuhan darah penderita talasemia dapat tercukupi setiap kali melakukan transfusi sehingga penderita talasemia dapat mempertahankan hidupnya dengan baik. ${ }^{9}$ Tujuan dari penelitian ini adalah membuat model predikasi kebutuhan darah pada penderita talasemia mayor.

\section{Metode}

Penelitian observasional ini menggunakan desain penelitian potong lintang. Variabel bebas yang diteliti yaitu usia, jenis kelamin, golongan darah, berat badan, kadar $\mathrm{Hb}$, dan riwayat splenektomi. Variabel terikat kebutuhan darah yaitu jumlah rata-rata darah yang ditransfusikan pada penderita talasemia mayor setiap kali transfusi di rumah sakit. Populasi adalah seluruh penderita talasemia mayor yang melakukan transfusi di Rumah Sakit Umum Daerah (RSUD) Banyumas sebagai rumah sakit rujukan talasemia di wilayah Banyumas dan sekitarnya. Sampel adalah sebagian penderita talasemia mayor yang melakukan tranfusi di RSUD Kabupaten Banyumas pada tahun 2012 berdasar kriteria inklusi dan ekslusi berjumlah 79 penderita. Kriteria inklusi adalah penderita melakukan tranfusi darah secara rutin minimal satu bulan sekali selama tahun 2012. Kriteria eksklusi tidak tersedia data yang lengkap dari variabel yang akan diteliti. Sumber data yang digunakan adalah data sekunder penderita talasemia mayor selama 12 bulan, berupa data time series per bulan selama 1 tahun, di RSUD Kabupaten Banyumas. Terdapat 1.134 pengamatan yang diperoleh dari 79 penderita yang melakukan transfusi minimal satu bulan sekali selama tahun 2012. Analisis statistik yang digunakan untuk mendapatkan model prediksi kebutuhan darah adalah regresi linier berganda.

\section{Hasil}

Penderita talasemia mayor yang melakukan transfusi rutin setiap bulan selama 1 tahun rata-rata berusia 11,8 tahun, ada yang mulai melakukan transfusi sejak berusia 2 tahun. Jenis kelamin perempuan $(61,8 \%)$ dengan golongan darah terbanyak adalah golongan $\mathrm{O}(38,0 \%)$, B $(30,4 \%)$ dan A $(25,3 \%)$. Rata-rata berat badan adalah $25,54 \mathrm{~kg}$. Pada subjek yang berusia dua tahun dengan berat badan terendah adalah 9 kilogram, rata-rata kadar $\mathrm{Hb}$ adalah 8,158 gr/dL dengan kadar $\mathrm{Hb}$ terendah 3,9 $\mathrm{g} / \mathrm{dL}$ dan tertinggi 10,8 g/dL. Kadar Hb sangat diperhitungkan dalam pemenuhan kebutuhan darah transfusi, jika seseorang dengan kadar $\mathrm{Hb}$ yang rendah dibutuhkan lebih banyak darah tranfusi untuk meningkatkan $\mathrm{Hb}$ sesuai dengan target yang ingin dicapai sekitar $10-$ $13 \mathrm{~g} / \mathrm{dL}$. Ada lima orang $(6,3 \%)$ pasien yang pernah menjalani splenektomi dengan usia rata-rata adalah 15,2 tahun. Rata-rata kebutuhan darah pada tahun 2012 adalah 404,85 mililiter. Volume darah pada kantong darah ada yang berukuran 220 mililiter dan ada yang berukuran 110 mililiter sehingga berapa kantong yang akan diberikan disesuaikan dengan jumlah kebutuhan darahnya (Tabel 1).

Analisis multivariat dengan regresi linier ganda digunakan untuk menentukan faktor yang berpengaruh terhadap kebutuhan darah penderita talasemia mayor. Ada tiga variabel yang berpengaruh bersama-sama terhadap kebutuhan darah penderita talasemia mayor meliputi berat badan, kadar Hb sebelum tranfusi, dan usia (Tabel 2).

Hasil analisis menemukan nilai $\mathrm{R}$ adalah 0,898 yang berarti korelasi antara variabel usia, berat badan, dan kadar $\mathrm{Hb}$ dengan kebutuhan darah adalah sangat kuat karena nilai $\mathrm{R}$ tersebut lebih dari 0,5 dan hampir mendekati nilai 1 . Nilai $\mathrm{R}$ square 0,807 $(0,807 \beta 100 \%=$ $80,7 \%$ ) menjelaskan bahwa sekitar $80,7 \%$ kebutuhan 
Tabel 1. Karakteristik Penderita Talasemia Mayor

\begin{tabular}{|c|c|c|c|}
\hline Variabel & Kategori & $\mathbf{n}$ & $\%$ \\
\hline \multirow[t]{2}{*}{ Jenis kelamin } & Laki-laki & 31 & 39,2 \\
\hline & Perempuan & 48 & 60,8 \\
\hline \multirow[t]{4}{*}{ Golongan darah } & $\mathrm{O}$ & 30 & 38,0 \\
\hline & A & 20 & 5,3 \\
\hline & B & 24 & 30,4 \\
\hline & $\mathrm{AB}$ & 5 & 6,3 \\
\hline \multirow[t]{2}{*}{ Riwayat splenektomi } & Ya & 5 & 6,3 \\
\hline & Tidak & 74 & 93,7 \\
\hline \multirow[t]{4}{*}{ Usia (tahun) } & Rata rata & 11,8 & - \\
\hline & Minimal & 2 & - \\
\hline & Maksimal & 50 & - \\
\hline & $\mathrm{SD}$ & 9,05 & - \\
\hline \multirow[t]{4}{*}{ Berat badan (kg) } & Rata rata & 25,54 & - \\
\hline & Minimal & 9 & - \\
\hline & Maksimal & 50 & - \\
\hline & $\mathrm{SD}$ & 9,40 & - \\
\hline \multirow[t]{4}{*}{ Kadar $\mathrm{Hb}$ (gr/dL) } & Rata rata & 8,16 & - \\
\hline & Minimal & 3,9 & - \\
\hline & Maksimal & 10,8 & - \\
\hline & $\mathrm{SD}$ & 1,04 & - \\
\hline \multirow[t]{4}{*}{ Kebutuhan darah (L) } & Rata rata & 404,85 & - \\
\hline & Minimal & 125 & - \\
\hline & Maksimal & 1.230 & - \\
\hline & $\mathrm{SD}$ & 177,8 & - \\
\hline
\end{tabular}

Tabel 2. Analisis Multivariat

\begin{tabular}{lll}
\hline Variabel bebas & Nilai $\mathbf{p}$ & Variabel terikat \\
\hline Berat badan & 0,0001 & Kebutuhan darah penderita talasemia mayor \\
Kadar Hb & 0,0001 & \\
Usia & 0,016 & \\
\hline
\end{tabular}

Tabel 3. Hasil Model Persamaan Regresi

\begin{tabular}{lccc}
\hline $\mathbf{R}$ & R Square & Adjusted R Square & SSE \\
\hline 0,898 & 0,807 & 0,806 & 77,944 \\
\hline
\end{tabular}

Persamaan 1. Persamaan Regresi Kebutuhan Darah

Kebutuhan darah $=714+0,816($ usia $)+13,4($ berat badan $)-81($ kadar $\mathrm{Hb})$

darah dijelaskan oleh variabel usia, berat badan, dan kadar Hb. Sedangkan, 19,3\% dijelaskan oleh sebab lain (Tabel 3). Rumus prediksi juga menyatakan setiap kenaikan usia 1 tahun maka kebutuhan darah akan bertambah sebanyak 0,816 mililiter. Setiap kenaikan 1 kilogram berat badan, kebutuhan darah akan bertambah 13,4 mililiter, serta apabila kadar $\mathrm{Hb}$ mengalami penurunan 1 $\mathrm{g} / \mathrm{dL}$, kebutuhan darah akan bertambah sebesar 81 mililiter (Persamaan 1).

\section{Pembahasan}

\section{Karakteristik Penderita Talasemia Mayor}

Berdasarkan karakteristik jenis kelamin, laki-laki dan perempuan sama-sama dapat menderita talasemia, me- liputi $61,8 \%$ laki laki dan 38,2\% perempuan. Penelitian sebelumnya menyebutkan bahwa dari 15 penderita talasemia mayor, terdapat 12 orang laki-laki dan 3 orang perempuan. ${ }^{3}$ Usia mulai transfusi ada yang sejak 2 tahun, sedikit berbeda dengan penelitian sebelumnya, penderita talasemia berusia dengan kisaran $2-28$ tahun dengan median mulai transfusi 6 bulan (range $=3-120$ bulan). ${ }^{10}$ Faktor yang perlu dipertimbangkan ketika memulai tranfusi darah anak secara teratur adalah jika penderita talasemia tidak dapat mempertahankan tingkat hemoglobin diatas 50\% normal $(\leq 7 \mathrm{~g} / \mathrm{dL})$. Jika tumbuh kembang anak penderita talasemia tidak sesuai dengan grafik garis yang seharusnya, malah semakin turun, anak memerlukan tranfusi darah. Jika ada perubahan bentuk muka yang jelas, terutama jika terjadi ketulian akibat perkembangan sumsum tulang di dalam telinga atau patah tulang, juga menandakan kebutuhan memulai tranfusi darah. Jika seorang anak penderita talasemia mulai membutuhkan tranfusi di atas usia 5 atau 6 tahun dan mempunyai limpa yang besar, kemungkinan merupakan talasemia ringan. Jika limpa diangkat, beberapa penderita tersebut tidak memerlukan transfusi. ${ }^{11}$

Ada lima orang yang telah dilakukan splenektomi yang diindikasikan jika terjadi hipersplenisme sehingga membatasi gerak dan menimbulkan tekanan intraabdominal yang mengganggu pernapasan. ${ }^{12}$ Splenektomi diperlukan untuk menurunkan kebutuhan darah karena limpa yang besar meningkatkan kebutuhan darah dengan menambah penghancuran sel darah merah. ${ }^{13}$ Apabila limpa diangkat penghancuran darah akan berkurang sehingga terjadi peningkatan usia eritrosit, tetapi terjadi pula peningkatan risiko infeksi bakteri yang parah dan akut. ${ }^{14}$ Penelitian sebelumnya menemukan perbedaan bermakna antara rerata frekuensi transfusi darah pada penderita talasemia $\beta$ mayor prasplenektomi dengan pascasplenektomi. Rerata frekuensi transfusi darah prasplenektomi 15 kali per tahun, sedangkan pascasplenektomi menurun menjadi 8 kali per tahun per tahun. Hal ini dapat terjadi karena pasien yang telah menjalani splenektomi cenderung lebih rentan terkena penyakit infeksi yang mengancam kesehatan, termasuk penurunan kadar hemoglobin sehingga tetap membutuhkan darah yang banyak. ${ }^{15}$ Penderita talasemia mayor yang telah menjalani splenektomi, membutuhkan darah tranfusi lebih dari $250-275 \mathrm{~mL} / \mathrm{kg} / \mathrm{thn}$. Rata-rata kebutuhan darah pada tahun 2012 adalah 404,85 mililiter. Umumnya setiap pendonor diambil unit darah sekitar 450 mililiter. Sebelum diberikan pada pasien, plasma dan kebanyakan sel darah putih dipisahkan terlebih dahulu menjadi sekitar 250 mililiter sel darah merah (PRC) yang tertinggal dalam kantong darah.

Model Prediksi Kebutuhan Darah Penderita Talasemia Mayor Berat badan, kadar $\mathrm{Hb}$ dan usia memengaruhi ke- 
butuhan darah tranfusi penderita talasemia mayor. Hal ini berbeda dengan di rumah sakit, bahwa tranfusi darah hanya diberikan berdasarkan berat badan dan kadar $\mathrm{Hb}$. Selama ini, kebijakan pemberian tranfusi tersebut tidak membedakan jenis penyakit atau alasan pemberian tranfusi. Namun, model prediksi yang dihasilkan menunjukkan bahwa untuk penderita talasemia, faktor usia perlu diperhatikan meskipun pengaruh yang diberikan tidak sebesar faktor berat badan dan kadar $\mathrm{Hb}$. Model prediksi tersebut menyatakan bahwa laju pertambahan kebutuhan darah tranfusi untuk pasien yang berat badan tetap dan kadar $\mathrm{Hb}$ sebelum tranfusi sama dengan periode sebelumnya, meningkatkan kebutuhan transfusi seki$\operatorname{tar} 0,816 \mathrm{~mL} /$ tahun.

\section{Usia}

Usia berpengaruh pada kebutuhan darah tranfusi penderita talasemia. Setiap kenaikan satu tahun, maka kebutuhan darah akan bertambah sekita 0,816 mililiter. Hasil ini sesuai dengan penelitian sebelumnya, terdapat hubungan linier antara usia pasien talasemia mayor dengan jumlah transfusi darah yang diterima. Makin bertambah usia, frekuensi transfusi darah yang diterima setiap bulan juga meningkat karena makin bertambah usia, kondisi penyakit makin memburuk sehingga kebutuhan transfusi darah makin meningkat. ${ }^{16}$ Kebutuhan darah yang diperlukan pada setiap tranfusi berikutnya, pada penderita talasemia mayor, berangsur meningkat. Jumlah darah yang diberikan setiap tranfusi meningkat dengan peningkatan usia dan dengan pertumbuhan anak. Jika penderita mempunyai limpa yang besar yang penghancuran darah terlalu cepat, mereka membutuhkan darah lebih banyak, tetapi jika limpa sudah diangkat, kebutuhan darah mereka sedikit berkurang. ${ }^{11}$

Sebagian besar pasien yang berusia $0-5$ tahun menerima transfusi darah satu kali setiap bulan sedangkan pasien yang berusia $11-20$ tahun sebagian besar menerima transfusi darah dua kali setiap bulan. Pada penderita talasemia mayor, program tranfusi darah secara teratur akan lebih menjamin pertumbuhan dan perkembangan di masa anak-anak. ${ }^{17}$ Tranfusi darah yang teratur akan menjaga kadar Hb sekitar 9,5 - 10,5 g/dL dan pertumbuhan dan perkembangan anak normal sampai usia 10, bahkan 12 tahun. Di pihak lain, tranfusi berdampak negatif, berbagai komplikasi yang berhubungan dengan menumpuknya zat besi dalam tubuh. ${ }^{18}$

Penderita talasemia pada anak yang berusia $3-4$ tahun hanya memerlukan satu unit kantong darah, tetapi bersamaan dengan peningkatan usia sekitar 10 tahun, kebutuhan darah meningkat menjadi dua unit kantong darah, bersamaan dengan pertumbuhan dan perkembangan anak. Hal yang penting dalam perawatan anak talasemia adalah menjaga level $\mathrm{Hb}$ rata-rata tetap sama. Untuk itu, perencanaan jumlah unit kantong darah dan durasi waktu tranfusi harus dipertimbangkan. ${ }^{11}$

Menurut penelitian Shah et al., ${ }^{19}$ terdapat hubungan linier antara usia pasien talasemia $\beta$ mayor dengan jumlah transfusi darah yang diterimanya. Semakin bertambah usia, frekuensi transfusi darah yang diterima setiap bulan juga meningkat karena usia yang semakin bertambah, kondisi penyakit semakin memburuk sehingga kebutuhan transfusi semakin meningkat. Sebagian besar pasien yang berusia $0-5$ tahun menerima transfusi satu kali setiap bulan sedangkan pasien yang berusia 11 - 20 tahun sebagian besar menerima transfusi darah dua kali setiap bulan.

\section{Berat Badan}

Variabel berat badan berpengaruh pada kebutuhan tranfusi darah penderita talasemia mayor. Setiap kenaikan 1 kilogram berat badan, kebutuhan darah bertambah 13,4 mililiter. Berat badan termasuk variabel yang penting dalam menghitung kebutuhan darah pada setiap pasien yang akan melakukan transfusi. Dari waktu ke waktu, kebutuhan darah pada pasien yang lain juga dapat berbeda tergantung berat badan, apabila saat melakukan transfusi darah berat badan mengalami kenaikan dari waktu melakukan transfusi darah sebelumnya, kebutuhan darah saat itu cenderung mengalami kenaikan.

Penelitian ini mendukung penelitian di Hongkong sebelumnya. Usia dan berat badan berhubungan dengan kebutuhan darah maksimal disekitar usia 24 tahun dan berat badan 71,8 kilogram. Jenis kelamin dan riwayat splenektomi juga berpengaruh dengan batas bawah permintaan darah. Prediksi total permintaan darah akan meningkat $0,81 \%$ per tahun dari 13.459 unit pada tahun 2009 menjadi 15.183 unit pada tahun 2014. Kasus talasemia baru membutuhkan $31,7 \%$ dari seluruh permintaan darah pada tahun 2024. Kebutuhan darah mengalami peningkatan stabil sampai 10 tahun ke depan. ${ }^{20}$ Penelitian Guerin et al., ${ }^{21}$ menemukan variabel yang berpengaruh pada kebutuhan darah secara bivariat adalah kadar $\mathrm{Hb}$, berat badan, dan usia. Pada analisis multivariat, variabel yang terbukti berhubungan dengan kebutuhan darah adalah level $\mathrm{Hb}$.

\section{Kadar Hb Sebelum Tranfusi}

Selama ini, kadar $\mathrm{Hb}$ sebelum tranfusi dijadikan dasar petugas untuk menentukan kebutuhan darah. Sesuai dengan penelitian ini, kadar $\mathrm{Hb}$ sebelum tranfusi berpengaruh pada kebutuhan darah tranfusi. Apabila kadar $\mathrm{Hb}$ mengalami penurunan $1 \mathrm{~g} / \mathrm{dL}$, kebutuhan darah akan bertambah sebesar 81 mililiter. Kebutuhan darah pada satu pasien dengan pasien lain berbeda tergantung kadar $\mathrm{Hb}$ pra transfusi yang diperiksa saat akan menjalani transfusi darah. Transfusi darah diberikan pada pasien dengan kadar $\mathrm{Hb} \leq 10 \mathrm{~g} / \mathrm{dL}$. Penderita talasemia mayor dengan $\mathrm{Hb} 9-12 \mathrm{~g} / \mathrm{dL}$ dan tidak menunjukkan gejala kli- 
nis tidak diperlukan perawatan. ${ }^{21}$

Pada penderita talasemia, level $\mathrm{Hb}$ akan turun sekitar $7 \%$ (atau $1 \mathrm{~g} / \mathrm{dL}$ ) setiap minggu. Apabila, seorang penderita talasemia mayor ditransfusi setiap empat minggu, level $\mathrm{Hb}$ turun sekitar $28 \%$ (4 g/dL), diperlukan darah yang dapat menaikkan $\mathrm{Hb}$ sekitar $28 \%$. Jadi, untuk meningkatkan level $\mathrm{Hb} 28 \%$ (4 g/dL) diperlukan 12 mililiter sel darah merah atau 20 mililiter darah pendonor per kilogram berat badan. Misalnya, jika berat badan penderita talasemia mayor 20 kilogram, diperlukan 240 mililiter sel darah merah (400 mililiter darah pendonor atau sekitar 2 kantong volume 220 mililiter) untuk meningkatkan level $\mathrm{Hb}$ sebanyak $4 \mathrm{~g} / \mathrm{dL} .{ }^{11}$

Dari berbagai penelitian tentang model prediksi kebutuhan darah saat tranfusi pada berbagai penyakit atau kelainan, variabel kadar $\mathrm{Hb}$ sebelum tranfusi selalu menjadi prediktor yang berpengaruh. Level $\mathrm{Hb}$ merupakan variabel prediktor dalam memprediksi kebutuhan darah pada penderita yang menjalani arthroplasty primer pinggul dan lutut. Pasien dengan level $\mathrm{Hb}<12$ g/dL membutuhkan 4 kali transfusi sehingga level $\mathrm{Hb}$ naik menjadi $>15 \mathrm{~g} / \mathrm{dL} .{ }^{21}$ Prediksi kebutuhan darah pada pembedahan, adalah level $\mathrm{Hb}<12,5 \mathrm{~g} / \mathrm{dL}$ menjadi variabel prediktor utama dalam prediksi kebutuhan darah. ${ }^{22}$

Level $\mathrm{Hb}$ pada penderita talasemia mayor seharusnya diukur setiap sebelum dan sesudah tranfusi sehingga dapat menghitung pelaksanaan tranfusi berikutnya. $\mathrm{Hb}$ sebelum tranfusi seharusnya tidak lebih rendah dari 70\% $(10 \mathrm{~g} / \mathrm{dL})$ dan tidak pernah dibawah $60 \%(8,6 \mathrm{~g} / \mathrm{dL})$, jadi sangat penting untuk mengukur level $\mathrm{Hb}$ secara teratur. ${ }^{11}$ Penelitian yang berbeda menyatakan bahwa kadar $\mathrm{Hb}$ minimal penderita talasemia sebelum tranfusi adalah $9 \mathrm{~g} / \mathrm{dL}$, dan untuk pasien dengan komplikasi jantung minimal $11-12 \mathrm{~g} / \mathrm{dL}$. Transfusi sebaiknya diberikan secara rutin 2 - 5 minggu untuk menjaga level $\mathrm{Hb}$ antara 9,5 - 10,5 g/dL. ${ }^{23}$ Setiap pasien talasemia mayor membutuhkan darah yang berbeda pada saat tranfusi. Kebanyakan pasien yang limpanya telah diangkat membutuhkan darah yang relatif sama. Pasien dengan limpa normal umumnya membutuhkan darah $20-30 \%$ lebih banyak dibandingkan pasien yang telah diangkat limpanya. Pasien yang limpanya sangat aktif dapat membutuhkan darah 2 sampai 3 kali lipat lebih banyak dibandingkan pasien lain. Dalam kasus ini limpa tersebut seharusnya diangkat. ${ }^{11}$

\section{Kesimpulan}

Sekitar 80,7\% kebutuhan darah tranfusi penderita talasemia mayor dijelaskan oleh variabel usia, berat badan dan kadar $\mathrm{Hb}$ sebelum tranfusi. Setiap kenaikan usia 1 tahun maka kebutuhan darah akan bertambah sebanyak 0,816 mililiter, kenaikan 1 kilogram berat badan maka kebutuhan darah akan bertambah 13,4 mililiter, serta apabila kadar $\mathrm{Hb}$ mengalami penurunan $1 \mathrm{~g} / \mathrm{dL}$ maka kebutuhan darah bertambah sebesar 81 mililiter.

\section{Saran}

Faktor usia, berat badan, kadar $\mathrm{Hb}$ sebelum transfusi menjadi faktor yang harus diperhitungkan pada saat menghitung kebutuhan darah transfusi bagi penderita talasemia mayor.

\section{Ucapan Terima Kasih}

Terima kasih kepada RSUD Banyumas dan LPPM Unsoed. Penelitian ini adalah bagian dari Penelitian Unggulan Perguruan Tinggi - BOPTN yang dibiayai oleh DIPA Unsoed BOPTN dengan Nomor Surat Perjanjian 2740/UN23.10/PN/2013.

\section{Daftar Pustaka}

1. Nasir JA, Zaidi SAA. Modeling survival data of thalassemia patients in Pakistan. Journal of Ayub Medical College. 2009; 21(1): 142-5.

2. Modella B, Matthew D. Global epidemiology of haemoglobin disorders and derived service indicators. Bulletin of the World Health Organization. 2008; 86 (6): 480-7.

3. Shivashankara AR, Jailkhani R, Kini A. Hemoglobinopathies in Dharwad, North Karnataka: a hospital-based study. Journal of Clinical and Diagnostic Research. 2008; 2 (1): 593-9.

4. Mariani D. Analisis faktor yang mempengaruhi kualitas hidup anak thalasemia beta mayor di RSU Kota Tasikmalaya dan Ciamis [Tesis]. Depok: Fakultas Ilmu Keperawatan Universitas Indonesia; 2011.

5. Departemen Kesehatan Republik Indonesia. 2008. Riskesdas 2007 Laporan Provinsi Jawa Tengah. Jakarta: Badan Penelitian dan Pengembangan Kesehatan Departemen Kesehatan Republik Indonesia; 2008.

6. Unit Pelayanan Talasemia RSUD Banyumas. Buku laporan pasien talasemia. Banyumas; Unit Pelayanan Talasemia RSUD Banyumas; 2012.

7. Ganie RA. Thalassemia: permasalahan dan penanganannya. Gelanggang Mahasiswa Universitas Sumatra Utara. Pidato Pengukuhan Jabatan Guru Besar Tetap. Medan pada Tanggal 16 November 2005. Medan: Universitas Sumatera Utara; 2005.

8. Bulan S. Faktor-faktor yang berhubungan dengan kualitas hidup anak thalassemia beta mayor [Tesis]. Semarang: Program Pascasarjana Magister Ilmu Biomedik dan Program Pendidikan Dokter Spesialis Ilmu Kesehatan Anak, Universitas Diponegoro; 2009.

9. Rejeki DSS, Nurhayati N, Supriyanto, Kartikasari P. Studi epidemiologi deskriptif talasemia. Kesmas Jurnal Kesehatan Masyarakat Nasional. 2012; 7 (3): 139-44.

10. Hashemi A. Ghilian R, Golestan M, Ghalibaf AM, Zare Z, Dehghani MA. The study of growth in thalasemic patients and its correlation with serum ferritin level. Iranian Journal of Pediatric Hematology Oncology. 2011; 1 (4); 147-51.

11. Vullo R, Bernadette M, Georganda E. What is thalassemia. Nicosia: Thalassemia International Federation World Health Organization; 1995.

12. Atiek SA, Husna, Purnaan J. Buku Kapita Selekta Kedokteran. Jakarta: Media Aesculapius; 2000.

13. Haffbrand AV, Pettit JE. Hematologi (essensial hematology). Darmawan I, penterjemah. Jakarta: EGC; 1996.

14. Sacher RA, McPherson RA. Tinjauan klinis hasil pemeriksaan labora- 
torium. Jakarta: EGC; 2004.

15. Andriastuti M, Teni TS, Pustika AW, Siti AP. Kebutuhan transfusi darah pasca-splenektomi pada talasemia mayor. Jurnal Sari Pediatri. 2011;13 (4): 244-9.

16. Shah N, Anupa M, Dhaval C, Vora C, Shah NR. Effectiveness of transfusion program in thalassemia major patients receiving multiple blood transfusions at a transfusion centre in Western India. Asian Journal of Transfusion Science. 2010; 4 (2): 94-8.

17. Ritesh NS, Pancholi SS. Oral iron chelator: a new avenue for the management of current pharmaceutical research. 2010; 01: 1-7.

18. Galebello R, Raffaell G. Beta thalassemia. Orphanet Journal of Rare Disease. 2010; 5: 11.

19. Shah N, Anupa M, Dhaval C, Vora C, dan NR Shah. Study of effectiveness of transfusion program in thalassemia major patients receiving multiple blood transfusions at a transfusion centre in Western India. Asia
Journal of Transfusion Science. 2010; 4 (2): 94-8.

20. Lau EHY, He Xiu-Qing, Lee Cheuk-Kwong, Wu Joseph T. Predicting future blood demand from thalassemia mayor patients in Hong Kong. PLOS ONE. [serial on the internet]. 2013; [cited 2013 Nov 5] 5 : [about 5 p]. Available from: http://http://www.ncbi.nlm.nih.gov/pubmed/24349138.

21. Guerin S, Collins C, Kapoor H, McCleant, Collins D. Blood transfusion requirement prediction in patiens undergoing primary total hip and knee arthroplasty. Transfusion Medicine. 2007; 17: 37-43.

22. Cockcain AJ, Masudi T, Lodge JPA, Toodood GJ, Prasad KR. Predictors of blood transfusion requirement in elective liver resection. HPB (Hepato-Pancreato-Biliary Association). 2010; 12(1): 50-5.

23. Qari MH, Wali Y, Albagshi MH, Alshahrani M, Alzahrani A, Alhijji I, et al. Opinion for the management of beta thalassemia mayor in the Arabia Gulf Area. Orphanet Journal of Rare Disease. 2013; 8: 143. 